\title{
A Positive Perspective to Implementation of a Gender Equality Plan: a question of design, time and participation
}

\author{
Victor F. A. Barros \\ ALGORITMI Research Centre \\ University of Minho \\ Guimarães, Portugal \\ vfbarros@dsi.uminho.pt \\ Luis Amaral \\ ALGORITMI Research Centre \\ University of Minho \\ Guimarães, Portugal \\ amaral@dsi.uminho.pt
}

\author{
Rosa M. Vasconcelos \\ 2C2T Research Center \\ University of Minho \\ Guimarães, Portugal \\ rosa@det.uminho.pt \\ Isabel Ramos \\ ALGORITMI Research Centre \\ University of Minho \\ Guimarães, Portugal \\ iramos@dsi.uminho.pt
}

\author{
Emília Araújo \\ Communication and Society Research \\ Centre \\ University of Minho \\ Braga, Portugal \\ era@ics.uminho.pt
}

\begin{abstract}
This paper describes the initial steps of a project developed with the aim of fostering diversity and the gender equality at the University of Minho, with a particular focus on the school of engineering. The project follows the actionresearch method, starting by gathering the perspectives of the various organizational participants (academics, nonacademics, researchers, and students). The insights emerging from the collected information supported the definition and the prioritization of actions and activities of the Gender Equality Plan. Four levels of intervention were considered: Human Resources and Management Practices, Research Content and Delivery, Teaching and Students' Services and Institutional Communication, under the EQUAL-IST Project (Gender Equality Plans for Information Sciences and Technology Research Institutions). The techniques used to gather the supporting information included interviews with decision makers, as well as focus groups with students, teachers, and academic staff at the School of Engineering. From the analysis of the gathered information emerged a set of challenges and opportunities to improve gender equality. The Gender Equality Plan (GEP) now being implemented at the university addresses the identified challenges and integrates actions to seize the opportunities to achieve greater gender equality. GEP was designed in line with 3 main goals: raise awareness, implement structural changes and engage stakeholders in mind-set change.
\end{abstract}

Keywords—gender equality plan, diversity, diagnosis, actionresearch methodology.

\section{INTRODUCTION}

Gender in the higher education institutions have attracted increasing attention over the past twenty years in many different scientific fields [1-8]. During the same period, numerous actions were undertaken to reduce the existing gaps between women and man in academy and in research. Nevertheless, various authors still underscore the persistence of gender disparities in academy and in research centres in several countries [9-13].

Notwithstanding, the gender mainstreaming is ever more invoked as a crucial way of mitigating gender inequalities and lead institutions to adapt and change in what concerns gender relations within academic contexts. Despite the policy improvements as regards the fostering of gender equality in academic contexts, there is still a great deal of resistance to implement these policies and make them effective, particularly in the IST field, and Portugal is not an exception [9-13].

Based on this understanding, this text describes the first interaction of the design of the Gender Equality Plan of the University of Minho (UMINHO GEP). The GEP was developed under the auspices of the European Project H2020, titled "EQUAL-IST - Gender Equality Plans for Information Sciences and Technology Research Institutions" which involves eight Research Performing Organisations (RPOs) from Northern, Southern, and Central European countries, as well as one CIS (Commonwealth of Independent States).

The project aims to enhance gender equality in Information Sciences and Technology (IST) and aspires to lead university elites to commit with structural changes concerning the reduction of gender violence in academy. It adopts the action-research method. As a research method, it has several clear benefits for defining structural changes in organizations. First, it allows tackling with the ongoing communication, interaction and decision processes, as well as the role of structures in shaping them. Secondly, it ensures active involvement of participants in the research activities since the results will have a direct impact in improving their understanding of faced problems and in identifying effective solutions. Thirdly, it allows to stay in the organization long enough to understand the impact of changes suggested by researchers and implemented in the context of the project.

Therefore, following the action-research methodology assumptions, the paper will be focused on presenting the first step undertaken with the view to explore the problem and obtain information useful both for understanding the state of gender relationships in IST at the university; in this first stage the main challenges and barriers to address during the design and implementation of a Gender Equality Plan were identified. Before approaching these topics, there is a need to understand more broadly what a gender equality plan is.

\section{DEFINING A GENDER EQUALITY PLAN FOR THE UNIVERSITY}

Gender equality plans are part of the European strategies to enhance gender equality in academic contexts. They integrate the gender mainstreaming strategies that were particularly nurtured since 2012, after the publication of the European directive 'A Reinforced European Research Area 
Partnership for Excellence and Growth' [14]. Its main objective was to "end the waste of talent which we cannot afford and diversify views and approaches in research and foster excellence" [15, p.4].

The European Institute for the Equality of Gender advances several key ideas to develop a Gender Equality Plan at the Universities. Typically, a gender plan implies establishing and making effective a set of basic principles to safeguard gender equality in all the spheres of academic life. It also establishes the core actions to be developed in the university, across its different levels: human resources practices and management processes, student services and institutional communication, research design and delivery, and institutional communication.

Facing the present day academic contexts of increasing mobility, globalization and knowledge circulation, it is commonly accepted that it is urgent that science and education policies, (including teachers and non-teaching staff as well as students and researchers) recognize gender inequalities and promote effective measures for its eradication, in a collective and participatory approach.

In some cases, Gender Equality Plans have been disparaged for their lack of success; the low involvement of people in the process is often considered the main reason for that failure [16-19]. However they are also recognized as core instruments for generating gender equality awareness and act towards cultural change on matters linked to gender violence eradication. Issues like time managing and organizational participation are considered fundamental for designing and implementing a gender plan, as the process is not linear.

By integrating a strong dimension of action research, the EQUAL-IST Project aimed precisely to encourage the participation of all the Schools and Institutes of the University of Minho (UMINHO), thus responding to the European guidelines which recommended the use of participatory methodologies in every phase of the Gender Plan implementation.

The paper will now focus on the first stage of the project characterized by the use of qualitative techniques to gather information.

\section{DESIGN OF GENDER EQUALITY PLAN AT THE UNIVERSITY OF MINHO: OVERVIEW OF THE METHOD, CHALLENGES \& RESISTANCES}

The action-research methodology encompasses several steps in order to produce structural changes in organizations [20-23]. The Figure 1 shows these main steps as followed in the research project.

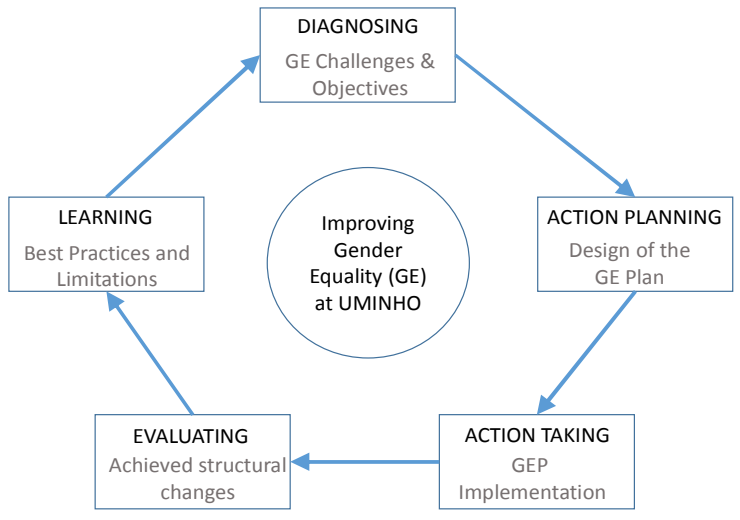

Fig. 1. Approach to improve Gender Equality at the University.

\section{A. Overview of the method}

UMINHO currently has about 20.000 students. Being 43 years old, and despite its high degree of internationalization and involvement with the surrounding community, it presents several layers of gender inequality across the different scientific areas.

Very synthetically and focusing the situation at the School of Engineering - one of the 11 schools and institutes of the University of Minho -, the data in Table 1 shows that in the Schools of Engineering scientific work is mainly done by men $(76,8 \%$ academics and $58 \%$ researchers) while administrative work is done by women (55\%). Furthermore, the percentage of female students is very low $(30 \%)$, when compared to male students $(70 \%)$.

Table 1. Some collected data from School of Engineering of University of Minho disaggregated by gender.

\begin{tabular}{|l|c|c|c|c|c|} 
& \multicolumn{3}{|c|}{$\begin{array}{c}\text { School of } \\
\text { Engineering }\end{array}$} & $\begin{array}{c}\text { University } \\
\text { of Minho }\end{array}$ & $\begin{array}{c}\text { National } \\
\text { Level }\end{array}$ \\
\cline { 2 - 6 } & Female & Male & $\begin{array}{c}\text { \% } \\
\text { Female }\end{array}$ & $\begin{array}{c}\text { \% } \\
\text { Female }\end{array}$ & $\begin{array}{c}\text { \% } \\
\text { Female }\end{array}$ \\
\hline Academic Staff & 76 & 251 & $\mathbf{2 3 , 2}$ & $\mathbf{4 2 , 0}$ & $\mathbf{4 0 , 0}$ \\
\hline $\begin{array}{l}\text { Researcher staff, } \\
\text { Research grants, } \\
\begin{array}{l}\text { Other academic } \\
\text { staff }\end{array}\end{array}$ & 197 & 278 & $\mathbf{4 1 , 5}$ & - & $\mathbf{4 6 , 0}$ \\
\hline $\begin{array}{l}\text { Non-Academic } \\
\text { Staff }\end{array}$ & 44 & 35 & $\mathbf{5 5 , 7}$ & $\mathbf{6 5 , 0}$ & - \\
\hline $\begin{array}{l}\text { Students (1 } \\
3^{\text {rd }} \text { cycles) }\end{array}$ & 1347 & 3145 & $\mathbf{3 0 , 0}$ & $\mathbf{5 4 , 0}$ & $\mathbf{4 0 , 8}$ \\
\hline
\end{tabular}

Source: collected and aggregated by authors from database of University of Minho, 2016; and General Direction for Education and Science Statistics (DGEEC).

It is also important to emphasize that, at the level of academics at the School of Engineering, women are poorly represented in the position of Full Professors. Confirming the existence of the glass ceiling, only $7 \%$ of the full professors at the School of Engineering are women. At the research level, only $21 \%$ of projects running in School of Engineering are led by women. At the students' level, of the 14 graduate's programs offered at the Engineering School, only 04 (28.6\%) have a female predominance.

In order to obtain more details and explanations for the disparities encountered in the numbers, the first stage of this project implied the use of qualitative techniques: interviews and focus groups. At this initial stage and considering that the project was dealing with an unknown and implicit reality, the participants were mostly chosen taking into account the need to explore the diverse angles of the same problem, obtaining information about the several variables considered and problematized theoretically. This procedure 
encompasses some limitations because it does not secure a statistical representativeness. However, as stated by qualitative authors [, the applied techniques aim at gaining a broad vision of the problem, and of its intersectionality achieving another type of representativeness that deals with the nature of the problems being addressed.

\section{The Interviews}

The interviews conducted at this stage of the research served not only to collect data about the different perspectives on gender inequality at the university and to foster trust and adhesion to the project. The selection of the interviewees in this phase involved the respect for diversity of gender, and academic situation, struggling for listening to decision makers both at the university level, and at engineering school.

In total, 12 interviews were conducted - 07 women $(58,3 \%)$ and 05 men $(41,7 \%)$ at this stage:

Rectorate (3W, 2M):

- Vice Dean of Internationalization (W)

- Director of Internationalization (W)

- Director of the Inclusion Office (M)

- Chief of Central Institutional Communication Office (W)

- Member of Central Institutional Communication Office (M)

School of Engineering (4W, 3M):

- Vice Head of the School of Engineering (W)

- Director of Department of Information Systems (M)

- Full professor at the department of Information Systems (M)

- Director of the Doctoral Program in Information Systems and Technology (W)

- Director of Communication Office of the School of Engineering (W)

- Member of Communication Office of the School of Engineering (M)

- Researcher of Doctoral Program in Information Systems and Technology (W)

As stated, the goal at this step was to analyse the degree of openness of decision makers to speak about gender inequalities in a broad sense. Therefore, the interview guide included a set of questions that were then adapted to each interviewee.

1. What do you consider to be the main queries regarding gender equality (at the university level, and IST areas particularly)?

2. In your opinion, how and to what extent are they perceived (at the university level, and IST areas particularly)?

3. In your opinion, which are the possible actions/strategies that could be useful to apply in order to improve gender equality (at the university level, and IST areas particularly)?

4. And which main obstacles do you envisage for their application (at the university level, and IST areas particularly)?
5. Please describe if there is any on-going or planned future action to improve gender equality (at the university level, and IST areas particularly).

6. Please add any other remarks about the issue.

Most part of the interviewees begun considering that gender equality was not a problem in their area of activity. However, interviews proved to be extremely insightful, as they allowed interviewees to deal with their misconceptions on gender issues in academic contexts. Thus, during the interviews some of them changed their view and declared themselves more aware of the difficulties imposed upon women progress and recognition in science and academy.

\section{The Workshops}

Three workshops were implemented with students, teachers and researchers, and non-academic staff. They were organized to promote discussion and identification of challenges concerning gender inequality issues. They aimed at deepening knowledge about several dimensions of analysis defined according to the theoretical framework on gender and academy. To note, the project encompasses several workshops with different publics, including stakeholders, such as labour market entities. In this initial phase the workshops were only implemented in the UMINHO's engineering school. They aimed to explore the problem and identify gender equality challenges regarding the access and permanence of women in IST fields. Subsequently, they focused also the respect for diversity of gender in the various academic positions. In the case of the students, the workshops integrated women and men from different programs offered by the Engineering School.

The workshops lasted for about 40 minutes. Active methodologies were used to foster people participation. The Workshops involved the participation of 18 women $(53 \%)$ and 16 men $(47 \%)$.

In short, a timeline showing the main changes in female role's occurring in Portugal after the democratic revolution in 1974 was presented to facilitate the discussion. After explaining the timeline, the participants, divided in groups, were invited to read the information posted in the timeline and to think about the images and other graphs displayed. Once seated, the participants were asked about their opinion on the information provided by the timeline, namely about the changes they considered more important and why.

Following the timeline exercise, participants were asked to answer a questionnaire. This questionnaire included a list of questions addressing some of the main problems and challenges identified in existing studies about gender equality issues in higher education. The participants were asked to indicate their level of agreement with each sentence pointing to problems and challenges classified according to its seriousness and occurrence at the School of Engineering, in the University of Minho. This classification was done individually. The answers were written on a Cartesian plan, in which the $\mathrm{X}$ coordinate referred to the gravity of the Problem/Challenge and $\mathrm{Y}$ coordinate referred to the degree of occurrence in the University of Minho. The seriousness versus occurrence was classified from 0 to 5 ( 0 no intensity and 5 great intensity).

The individual answers were then discussed in group and another Cartesian plan was developed to achieve consensus 
about the problems. Divergences were discussed to obtain further insights about gender issues at the University.

Participants were cooperative, though also very resistant to speak and elaborate an oral answer. The use of guides and questionnaires was very important to begin the debates. Throughout the workshops the debate became more fluent and open. Still, men showed to be more resistant during the sessions to speak about issues like sexual division of labour, or sexual harassment.

After the discussion of the challenges, groups were then stimulated to signal in a previously prepared sheet, what were the main possible changes and good practices that should be implemented at the university to overcome the identified gender issues. The participants were then asked to form groups. Each group ordered five structural changes by degree of importance. In the end, a facilitator helped to share the conclusions of each group.

All the workshops were recorded, and notes were taken during the whole process. Having completed all stages, participants were asked about their level of satisfaction with the activities and the discussions. In general, the participants in the workshop were very engaged in the discussions and declared to be satisfied with the learning outputs of the exercises.

The workshops proved to be very important in gathering information about misconceptions and gender bias. Allowing people to speak and reflect about several issues concerning gender relationships in the academy and its impacts on careers and wellbeing, workshops were also strongly relevant in providing adequate contexts generating gender inequality awareness. That is, they helped in building up adequate contexts for leading people to debate and recommend capacity building measures for overcoming gender bias and inequalities within their working contexts. Most importantly, they allowed to obtain a first exploratory picture of the challenges and barriers the project would have to face and integrate in the gender equality plan.

\section{B. Challenges and Resistances}

The Table 2 displays the key contributions provided during this initial phase of qualitative data collection and that were integrated in the design of the gender equality plan.

Table 2. Main contributions from qualitative data collection and analysis.

- To increase awareness and reflexivity about gender bias in academy in all the dimensions, particularly as regards careers and work evaluation and promotion

Main contributions from qualitative data collection and analysis

- To promote female leadership

- To secure and care for the work/life balance.

- $\quad$ To build up a code of conduct regarding gender neutrality

As observed, data collection in this exploratory phase, combined with documental analysis and observation, clearly showed that gender equality in IST areas is a very complex matter, as it deals with many resistances, in great part coming from the male dominant academic culture. The table 3 displays the main critical issues for understanding gender equality in the university, as identified by the interviewees and participants in the workshops.
Table 3. Main critical issues identified by the research.

Low level of consciousness about gender inequality in academic and research contexts at the University

- Participants are convinced that there are no gender inequality issues to consider or change in IST
Main

critical

issues
- The great majority of participants in this research assume gender discrepancies in IST are normal, natural and dependent on how women and man envisage their work and life

$\circ \quad$ The number of women in decision making positions are often perceived as sole result of women's rational choices

- The number of female students in IST is understood as a result of individual choice

\section{CONTRIBUTES TO THE DESIGN OF GENDER EQUALITY \\ PLAN AT THE UNIVERSITY OF MINHO: A QUESTION OF DESIGN, TIME AND PARTICIPATION}

Table 4 displays the main actions addressed in the UMINHO GEP; they were designed in response to the main critical issues identified by organizational participants during the interviews and the workshops. In the table they are organized according to the main areas of intervention as addressed in the project: Human Resources and Management Practices; Research Content and Delivery; Teaching and Student Services; and Institutional Communication (Internal / External).

Table 4. Main measures addressed for the GEP of the University of Minho.

\begin{tabular}{|c|c|}
\hline Area & Measures \\
\hline $\begin{array}{l}\text { Human Resources and } \\
\text { Management Practices }\end{array}$ & 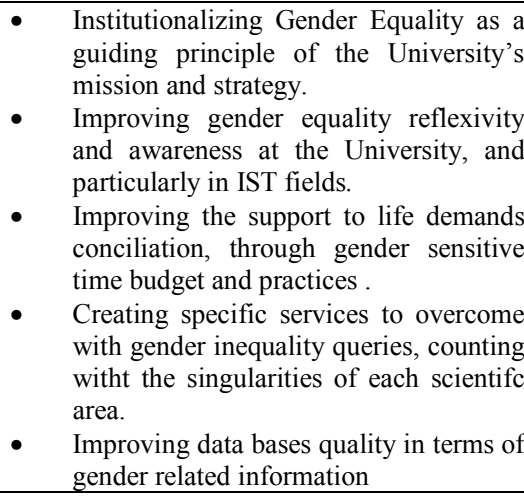 \\
\hline $\begin{array}{c}\text { Research Content and } \\
\text { Delivery }\end{array}$ & $\begin{array}{l}\text { - } \text { Recognizing, and encourage evaluators } \\
\text { to fairly evaluate personal CVs with } \\
\text { gender equality lenses, avoiding } \\
\text { descrimination concerning area and } \\
\text { sector of activity } \\
\text { - Fostering gender diversity in research } \\
\text { projects as well as in innovation design } \\
\text { Improving knowledge and learning } \\
\text { concerning the integration of gender in } \\
\text { all phases of innovation processes in } \\
\text { IST research related projects }\end{array}$ \\
\hline $\begin{array}{c}\text { Teaching and Students' } \\
\text { Services }\end{array}$ & $\begin{array}{l}\text { - Promoting better understanding of the } \\
\text { relevance of women in science and } \\
\text { encourage the increase of female } \\
\text { admission in IST study programs } \\
\text { Fighting against all forms of } \\
\text { descrimination of women student in IST } \\
\text { fields }\end{array}$ \\
\hline $\begin{array}{c}\text { Institutional } \\
\text { Communication } \\
\text { (Internal/External) }\end{array}$ & $\begin{array}{l}\text { - Promoting an effective communication } \\
\text { gender sensitive policy covering the } \\
\text { various dimensions of academic life } \\
\text { (teaching, research and management) }\end{array}$ \\
\hline
\end{tabular}

\section{FINAL REMARKS}

Gender equality is a multidimensional subject. This text described the very first steps of a project developed at the 
University of Minho, aiming to implement a gender equality plan, with a particular focus on the IST fields. Besides showing that qualitative methods can contribute to generate awareness about gender violence in academic contexts, particularly those that are still male dominated, this text also described the main critical areas identified by participants and that later on integrated the gender equality plan. In order to build a robust and solid basis for the gender equality plan, ensuring its successful adoption and sustainability after the project lifetime, this phase highlighted the need to consider the point of view of the actors involved, giving especial attention to their participation. This process of research and intervention is however lengthy and demands a lot of time for changing mind-sets and structures, but it is already recognized as a condition for conducting enduring and effective projects on this subject of study. A final word need to be addressed about limitations of the samples used in this phase and reflected in this paper. In fact, despite the integration of several methods and information sources, only an outline of the initial step was chosen to be presented in this paper, therefore providing a small picture of the situation at UMINHO. The university's situation is representative of the situation in most universities in Portugal. Portugal is a country where much has already been done concerning gender equality in science and academy [9], but where much more needs to be changed to reduce gender discrimination and male domination particularly [19], in IST fields.

\section{ACKNOWLEDGMENTS}

This work has been founded by the Portuguese Foundation for Science and Technology (FCT - Fundação para a Ciência e a Tecnologia) within the scope of the project UID/CEC/00319/2013, the research grant SFRH/BD/84939/2012 as well as FEDER and funds through the Competitivity Factors Operational programme COMPETE: POCI-01-0145-FEDER-007136 and POCI-010145-FEDER-007043 and FCT - Fundação para a Ciência e Tecnologia within the Project Scope: UID/CEC/00319/2013. and UID/CCI/00736/2013. This work is also part of a project that has received funding from the European Union's Horizon 2020 research and innovation programme under grant agreement $\mathrm{Nr} .710549$.

\section{REFERENCES}

[1] Bradley, K. (2000). The incorporation of women into higher education: Paradoxical outcomes?. Sociology of education, 73, 1-18.

[2] Brooks, G. R. (2001). Masculinity and men's mental health. Journal of American College Health, 49(6), 285-297.

[3] Fox, M. F., \& Stephan, P. E. (2001). Careers of young scientists: Preferences, prospects and realities by gender and field. Social studies of Science, 31(1), 109-122.

[4] Lawless, J. L., \& Fox, R. L. (2005). It takes a candidate: Why women don't run for office. Cambridge University Press.

[5] Stewart, A. J., Malley, J. E., \& LaVaque-Manty, D. (2007). Transforming science and engineering: Advancing academic women. University of Michigan Press

[6] Ceci, S. J., Williams, W. M., \& Barnett, S. M. (2009). Women's underrepresentation in science: sociocultural and biological considerations. Psychological bulletin, 135(2), 218.
[7] Gaughan, M., \& Bozeman, B. (2016). Using the prisms of gender and rank to interpret research collaboration power dynamics. Social Studies of Science, 46(4), 536-558.

[8] Pereira, M. D. M. (2014). Higher Education Cutbacks and the Reshaping of Epistemic Hierarchies: An Ethnography of the Case of Feminist Scholarship.Sociology, 44(2), 287 - 304.

[9] Amâncio, L., \& Ávila, P. (1995). O género na ciência. A Comunidade Científica Portuguesa nos Finais do Século XX, Oeiras, Celta Editora, 135-162.

[10] Delicado, A., \& de Almeida Alves, N. (2013). "Fugas de Cérebros", "Tetos de Vidro" e "Fugas na Canalização": mulheres, ciência e mobilidade. In Araujo, E.Fontes, M. \& Bento, S. (2012). Para um debate sobre mobildiade e fuga de cérebros (8-32), CECSPublicações/eBooks.

[11] Almeida, L. S., Guisande, M. A., Soares, A. P., \& Saavedra, L. (2006). Acesso e sucesso no ensino superior em Portugal: Questões de género, origem sócio-cultural e percurso académico dos alunos. Psicologia: Reflexão e Crítica, 19(3).

[12] Santos, G. G. (2004). O género e a carreira académica: Uma análise das barreiras organizacionais. Comportamento Organizacional e Gestão, 10, 241-260.

[13] Araújo, E., \& Barros, V. (2017). 'Modo Deadline': uma análise sobre o tempo das mulheres académicas. Revista Tempos e Espaços em Educação, 10(22), 173-186.

[14] COM (2012) Communication from the Commission to the European Parliament, the Council, the European Economic and Social Committee and the Committee of the Regions. Available: https://ec.europa.eu/digital-single-market/en/news/reinforcedeuropean-research-area-partnership-excellence-and-growth

[15] EUROPEAN COMISSION (2012). A Reinforced European Research Area Partnership for Excellence and Growth. Available: http://ec.europa.eu/transparency/regdoc/rep/1/2012/EN/1-2012-392EN-F1-1.Pdf

[16] Bergold, S., Wendt, H., Kasper, D., \& Steinmayr, R. (2017). Academic competencies: Their interrelatedness and gender differences at their high end. Journal of Educational Psychology, 109(3), 439p.

[17] Peterson, H., \& Jordansson, B. (2017). Gender Equality as a Core Academic Value: Undoing Gender in a 'Non-Traditional'Swedish University. In Gendered Success in Higher Education (pp. 27-47). Palgrave Macmillan, London.

[18] Nielsen, M. W. (2017). Scandinavian approaches to gender equality in academia: a comparative study. Scandinavian Journal of Educational Research, 61(3), 295-318.

[19] Sales Oliveira, Catarina y Augusto, Amélia (2017) El gender mainstreaming en la academia portuguesa. Ciencia, Técnica y Mainstreaming Social, 1,17-27.

[20] Baskerville, R. L., \& Wood-Harper, A. T. (1996). A critical perspective on action research as a method for information systems research. Journal of information Technology, 11(3), 235-246.

[21] Baskerville, R. L. (1999). Investigating information systems with action research. Communications of the AIS, v. 2, n. 3 esp., p. 4, 1999.

[22] Baskerville, R., \& Myers, M. D. (2004). Special issue on action research in information systems: Making IS research relevant to practice: Foreword. MIS quarterly, 329-335.

[23] Stringer, E. T. (2013). Action research. London:Sage Publication.

[24] Flick, W. (2014). An introduction to qualitative research. London: Sage.

[25] Augusto, A.Sales, C.; Araújo, E. \& Cerqueira, C. (2017). "The place for gender research in contemporary portuguese science and higher education policies within the context of neo-liberalism (107-128). In Kahlert H. (eds). Gender Studies and the New Academic Governance. Springer VS, Wiesbaden. 